\title{
Cara Berhukum Yang Benar Bagi Profesional Hukum (Ijtihad Sebagai Terobosan Hukum Progresif)
}

\author{
Oleh: Abdul Jamil \\ Dosen Fakultas Hukum UII Yogyakarta \\ e-mail:abduljamil@fh.uii.ac.id
}

\begin{abstract}
In the practical aspect, legal enforcement in Indonesia is still facing a controversy in terms of how a just verdict should be. The said controversy rooted deeply in the differences in the understanding towards the concept of normative law and the concept of progressive law. In the fact, most of legal apparatuses are still confined in normative law as a parameter of the verdicts that they conclude. On the other hand, from progressive law point of view, the existing legal norms are considered for not being a true reflection of the idea of justice. Consequently, the people then rely their hope for justice on the ability of lawyers to afford it
\end{abstract}

Keywords: Ijtihad, Profesional Hukum, Hukum Progresif

\section{Pendahuluan}

Konsep hukum modern yang dipaksakan berlakunya oleh pemerintah Hindia Belanda di Indonesia sebagai negara jajahan menciptakan perubahan cara berhukum bagi profesional hukum dalam menghadapi kasus sengketa. Profesional hukum yang dimaksud penulis adalah para penegak hukum (hakim, jaksa, polisi dan advokat). Kalau sekarang ini ada beberapa profersional hukum yang progresif meninggalkan ajaran Kolonial itu dianggap sebagai hal yang menyimpang dari keteraturan.

Sebagaimana diketahui dalam sejarah perkembangan hukum di Indonesia, sebelum berlakunya hukum modern abad XVII, Indonesia telah mengenal hukum yang hidup dalam masyarakat, yaitu hukum yang bersumber pada agama (Islam, Hindu) dan kebiasaan (adat). ${ }^{1}$ Dalam

\footnotetext{
${ }^{1}$ C.F.G. Sunaryati Hartono Sunario, "Pembinaan Hukum Nasiona Dalam Suasana Globalisasi masyarakat Dunia". Pidato Pengukuhan jabatan Guru Besar dalam Ilmu Hukum FH UNPAD, Bandung, 1991, hlm. 22
} 
kehidupan sebelumnya antara hukum agama dengan hukum adat tidak menimbulkan pertentangan, bahkan kadang-kadang menjadi seiring sejalan. Hal yang demikian dapat berjalan karena agama menjadi keyakinan dan penuntun jalan kebaikan manusia di muka bumi. Di sisi lain agama juga mengambil adat (kebiasaan) yang sudah hidup dalam masyarakat sebagai sumber hukum. Sebagai contoh di dalam Islam, sumber orang untuk menemukan hukum itu ada tiga, salah satunya adalah Ijtihad. Pengambilan hukum dalam berijtihad salah satu metodenya adalah menggunakan adat sebagai sumber.

Meotode ijtihad yang bersumber dari adat adalah kaidah yang terkenal berbunyi "al-adatu al-muhakkamah". Artinya adat kebiasaan itu dapat menjadi hukum. Meskipun tidak setiap adat dapat menjadi sumber hukum.

Dalam Islam, adat yang dapat dijadikan sebagai sumber hukum dalam ijtihad adalah adat kebiasaan yang hidup dalam sosial masyarakat dan tidak bertentangan dengan hukum Islam. Adat itulah yang dapat dipakai sebagai sumber hukum untuk menyelesaikan kasus sengketa dalam kehidupan manusia bermasyarakat.

Kaidah penggunaan hukum adat sebagai sumber hukum adalah sejalan dengan petata petiti dalam masyarakat Minangkabau, misalnya "Adat bersendi syara', Syara' bersendi kitabullah". ${ }^{2}$ Berdasarkan kalimat tersebut jelas antara adat dan hukum Islam pada suatu saat meminjam istilah yang digunakan oleh Daud Ali tidak dapat pisahkan. ${ }^{3}$ Artinya, bahwa Islam dan adat pada suatu saat berjalan seiring bersama menjadi hukum di tengah-tengah masyarakat .

Penghapusan hukum Islam dan penguatan hukum adat terbatas perkara perdata tertentu serta diberlakukannya hukum modern oleh pemerintah Hindia Belanda untuk negara jajahan yaitu Indonesia, menyebabkan seolah-olah bahwa antara hukum agama (Islam) dengan hukum adat selalu ada pertentangan. Keadaan yang demikian akhirnya mempengaruhi cara berhukum masyarakat dan profesional hukum dalam menghadapi kasus sengketa dewasa ini.

\footnotetext{
${ }^{2}$ Sajuti Thalib, Receptio A Contrario Hubungan Hukum adat dengan Hukum Islam, Ctk. Keempat, Jakarta: Bina Aksara, 1985, hlm. 61

${ }^{3}$ Daud Ali, Hukum Islam Hukum Islam : Pengantar Ilmu Hukum dan Tata Hukum Islam di Indonesia, Edsi kelima, Ctk.5, Jakarta : Raja Grafindo Persada, 1996, selanjutnya disebut Hukum Islam,
} 
Penghapusan hukum "lokal" yang sudah hidup berabad-abad dan digantikannya dengan hukum asing (Barat) belum tentu cocok untuk masyarakat tersebut, bahkan belum tentu hukum itu menimbulkan ketertiban. Sebab hukum tidak bisa dilepaskan dari rancangan besar mengenai bagaimana kehidupan manusia itu ingin dibangun. ${ }^{4}$ Hukum itu memiliki titik pandang dan akan berangkat dari situ pula. Cara pandang itu juga ditentukan oleh cara anggota-anggota dari bangsa itu berhubungan satu sama lain dalam anggota masyarakat. ${ }^{5}$

Apabila dibandingkan antara Timur dan Barat, khususnya bangsa Indonesia dengan Belanda mempunyai cara pandang yang berbeda. Barat (Belanda) anggota masyarakat dalam kehidupan sosialnya berfaham individualistis, sedangkan bangsa Indonesia dalam kehidupan sosial kemasyarakatannya bersifat kekeluargaan (komunalitas), ${ }^{6}$ berfaham kolektif, guyub, rukun dan masih banyak istilah lain yang mempunyai arti sama. Padahal hadirnya hukum sebagai ilmu yang baru menurut pendapat Brian Z. Tamanaha sebagaimana dikutip Satjipto dalam kemajemukan sebagai konsep hukum tidak berhenti hanya membincangkan hukum, melainkan dikaitkan dengan habitat sosial dimana hukum itu berada. ${ }^{7}$ Habitat suatu hukum bagi bangsa Indonesia menurut penulis adalah hukum yang sudah hidup dan sudah dijalankan di tengah-tengah masyarakat, atau yang dikenal dengan hukum agama (Islam, Hindu) dan adat.

Bertitik tolak dari pendapat Tamanaha tersebut, maka hukum tidak boleh keluar dari pola titik pandang masyarakat atau habitat sosial dimana hukum itu berada. Apabila hal itu terjadi maka tentu saja akan berdampak pada bagaimana cara anggota masyarakat menyelesaikan atau cara berhukum dalam menghadapi kasus sengketa dalam anggota masyarakatnya.

Masyarakat yang berfaham individualisme mempunyai kecenderungan penyelesaian kasus sengketa didasarkan pada kepentingan individualisme juga. Sedangkan masyarakat berfaham kekeluargaan,

${ }^{4}$ Satjipto Rahardja, Hukum dalam Jagat Ketertiban, bacaan mahasiswa Program Doktor Ilmu Hukum Universitas Diponegoro, Ctk. 1 Jakarta: UKI Press, 2006, hlm. 124

${ }^{5} \mathrm{Ibid}, \mathrm{hlm}, 125$

${ }^{6}$ C.F.G. Sunaryati Hartono Sunario, Op. Cit." hlm. 20-21

${ }^{7}$ Satjipto Rahardjo, "Kemajemukan sebagai KonsepHuku" makalahBacaan mahasiswa calon doktor Undip dalam mata kuliah ilmu hukum dan teori hukum No. 24. 20 Nopember 2007, hlm. 3. 
kolektif, guyub, rukun mempunyai kecenderungan menyelesaikan kasus sengketa dengan perdamaian. Sebab yang dijaga adalah kehormatan keluarga secara kolektif atau kelompok bukan individu anggota masyarakatnya.

Dalam konteks sekarang ini seharusnya bangsa Indonesia dapat mengembalikan cara pandang bangsa Indonesia yang masih hidup di tengah-tengah masyarakat dan pernah menghilang sampai berabad-abad, yaitu pola penyelesaian kasus sengketa dengan menjaga keseimbangan kepentingan masyarakat (komunalitas). Para profesional hukum dapat memahami rasa keadilan dalam masyarakat. Profesional hukum yang dimaksud oleh penulis adalah para penegak hukum yaitu hakim, jaksa, pengacara, polisi (catur wangsa), sebab pihak-pihak inilah sebagai penegak hukum di Indonesia. Sehingga para profesional hukum harus berani berijtihad secara proporsional yang didasari oleh kaidah-kaidah hukum yang berlaku dalam masyarakat.

\section{Perubahan paradigma lembaga perdamaian (hakam) menuju pengadilan}

Hukum yang berlaku di indonesia manakala dilihat dari sejarah perkembangannya sejak abad XVII telah dipengaruhi oleh hukum modern yang berfaham civil law yang dikembangkan oleh kolonial. Sistem hukum tersebut telah mempengaruhi dengan cara mereduksi hukum yang sudah ada sebelumnya yang waktu itu dikenal dengan sistem hukum yang hidup dalam masyarakat. Menggunakan istilah Prof Satjipto bahwa sistem hukum itu merupakan bentuk khas dari kehidupan sosial di situ (a piculiar form of social life). ${ }^{8}$ Pada waktu itu sistem hukum yang merupakan bentuk has kehidupan masyarakat sebelum abad XVII dikenal dengan sebutan hukum agama (Islam, Hindu) dan hukum adat, yang oleh Daniel S.Lev diartikan sebagai hukum lokal. ${ }^{9}$

Kedudukan hukum Islam melembaga dalam lingkungan masyarakat yang sudah dijalankan di bebarapa daerah di tanah air, dimulai sejak jaman kerajaan-kerajaan Islam telah berlaku, baik hukum pidana maupun hukum keluarga sesuai dengan pemahaman bersangkutan waktu itu. Bahkan hukum Islam sudah dikenal sejak sebelum tahun 1800 an, dan

\footnotetext{
${ }^{8}$ Satjipto Rahardjo, "Kemajemukan..., Ibid., hlm.3.

${ }^{9}$ Daniel S. Lev, Hukum dan Politik di Indonesia Kesinambungan dan Perubahan, penterjemah Wiyono dan AE. Priyono, Ctk. Pertama, Jakarta: LP3ES,1990, hlm. 425.
} 
tahun-tahun sesudahnya telah diakui oleh para ahli hukum dan ahli kebudayaan Belanda sendiri, bahwa di Indonesia berlaku hukum Islam. Masa ini kemudian dikenal dengan masa Receptio in Complexu ${ }^{10}$ yang dipersandingkan dengan ketentuan-ketentuan lama (adat) yang diungkapkan dengan istilah gebruiken der inlanders atau oude herkomsten. ${ }^{11}$

Kedua hukum yaitu Islam dan adat mempunyai kemiripan dalam mencapai tujuan hukum yaitu menciptakan keamanan dan ketertiban dalam kehidupan masyarakat (kemaslahatan) manusia. Dalam bahasa yang digunakan oleh Prof. Satjipto bahwa hukum adalah bagian dari usaha untuk menata ketertiban dalam masyarakat, meskipun tidak persis sama dengan ketertiban. ${ }^{12}$

Dalam kehidupan manusia, hukum yang bertujuan membuat ketertiban itu sering dilanggar sehingga menciptakan terganggunya tatanan sosial (order) dalam masyarakat. Ketika terjadi pelanggaran hukum sehingga mengganggu tatanan sosial masyarakat (disorder), tentu membutuhkan alat untuk menata, dalam perkembangan Islam di Indonesia disebut lembaga hakam atau lembaga damai (sekarang dikenal dengan nama pengadilan).

Lembaga hakam atau perdamaian merupakan model penegakan hukum lokal yang dikembangkan dalam hukum Islam pada jaman itu. Manakala terjadi adanya pelanggaran hukum atau kasus sengketa, maka pihak-pihak itu meminta bantuan pada lembaga hakam atau perdamaian. Karena yang dijaga bukan kepentingan individu, tetapi menjaga tatanan sosial masyarakat yang berdampak pada kepentingan kolektif atau kebersamaan.

Lembaga hakam atau lembaga perdamaian itu ternyata tidak hanya digunakan oleh masyarakat Islam saja, tetapi dikembangkan juga oleh adat. Bahkan perdamain yang dikembangkan oleh masyarakat adat ternyata masih berlaku sampai sekarang di era hukum modern ini. Sebagaimana contoh hasil penelitian Karolus Kopong sebagaimana dikutip oleh Satjipto, apapun jenisnya kasus sengketa di masyarakat Lamaholot Flores Nusa Tenggara Timur meskipun diselesaikan melalui jalur formal (peradilan), akan tetapi belum ada perdamaian antara pelaku dengan korbannya, maka sengketa kasus tersebut dianggap belum selesai. Oleh

\footnotetext{
${ }^{10}$ Sajuti Thalib, Ibid, hlm. 1-4

${ }^{11} \mathrm{Ibid}, \mathrm{hlm}$ 6-8

${ }^{12}$ Satjipto Rahardjo, Biarkan Hukum Mengalir Catatan Kritis tentang Pergulatan Manusia dan Hukum, Jakarta: Kompas, 2007, hlm. 21-22
} 
karenanya ketika terjadi sengketa kasus selalu diselesaikan hingga ke tahapan perdamaian melalui ritus adat yang disebut mela sereka (ritus perdamaian) meskipun ada putusan pengadilan secara formal. ${ }^{13}$

Lembaga perdamaian hakam dalam Islam maupun adat merupakan lemgaba hukum yang hidup dan diakui oleh anggota masyarakat Indonesia, akan tetapi kemudian lembaga ini telah diganti oleh hukum Barat (hukum modern) yang berparadigma individualisme. Sehingga oleh pemerintah Hindia Belanda hukum keperdataan dan pidana telah diganti dengan hukum Barat, sedangkan hukum keluarga yang bersumber dari hukum Islam diganti hukum sebagian diganti oleh hukum Barat dan sebagian lagi adat.

Penggantian hukum Islam yang sudah hidup di dalam lingkungan sosial masyarakat yang secara sadar telah di jalankan oleh masyarakat didasarkan atas lahirnya teori Receptie dari Chritiaan Snouck Hurgonje. ${ }^{14}$

Sejak lahirnya theori Receptie tersebut lembaga perdamaian yang dikenal masyarakat Islam (termasuk di dalamnya adat) hilang dari tatanan kehidupan sosial masyarakat dan telah diganti pengadilan (Landraad) yang sekarang dikenal dengan Pengadilan Negeri. Sebab adat yang diakui hanya sebagai konsep hukum, sedangkan konsep peradilannya melebur dalam peradilan Landraad. Padahal di dalam adat juga dikenal adanya peradilan adat yang menyelesaikan kasus sengketa di dalam masyarakat.

Dampak berlakunya theori receptie yang menghapus hukum Islam itu tidak saja berhenti pada konsep hukum yang sudah berlaku, tetapi juga sampai pada perombakan pengadilan. Pengadilan agama (raad agama) konsep Snouck Hurgronje merupakan perombakan konsep peradilan dari lembaga Hakam. Hakam dalam menyelesaikan masalah menggunakan jalur perdamaian, meskipun proses menyelesaikan dengan jalan damai itu menggunakan prinsip-prinsip peradilan, yaitu ulama' (kiyai) yang dianggap tahu tentang hukum itu berperan sebagai hakim dan juga sebagai juru damai. Hakam inilah yang merupakan embrio Peradilan Agama hususnya dan pengadilan landraad di Indonesia. ${ }^{15}$

Dari konsep hakam tersebut akhirnya berkembang pengadilan Islam di Indonesia, dan mulai dilembagakan pada kelompok-kelompok

${ }^{13}$ Ibid, hlm. 53-54

${ }^{14} \mathrm{Ibid}, \mathrm{hlm} 10-11$

${ }^{15}$ Mohammad Daud Ali, Hukum Islam...Op. Cit, hlm. 210. Baca juga Daniel S. Lev Peradilan Agama Islam di Indonesia, alih bahasa H. Zaini Ahmad Noeh, Ctk . kedua, Jakarta: Intermasa, 1986, hlm.2 
masyarakat yang diperintah oleh penguasa (raja) muslim dalam menyelesaikan kasus perkara yang timbul dalam masyarakat.

Apabila dilihat dari kenyataan tersebut, suatu kewajaran ketika orang sudah menyatakan Islam, secara otomatis mereka menerima seluruh ketentuan ajaran Islam sebagai bagian dari kehidupan mereka termasuk hukumnya. Sebagaimana dikemukakan oleh HAR Gibb yang terkenal dengan teori penerimaan Otoritas Hukum dalam bukunya The Modern Trends of Islam, teori tersebut menjelaskan bahwa apabila orang Islam telah menerima Islam sebagai agamanya, maka ia menerima otoritas hukum Islam terhadap dirinya. ${ }^{16} \mathrm{Hal}$ ini sejalan dengan teori Receptio in Complexu dari L.W.C. van den Berg bahwa bagi orang Islam berlaku penuh hukum Islam sebab dia telah memeluk agama Islam. ${ }^{17}$ Ketika mereka sudah menerima Islam termasuk di dalamnya adalah hukum Islam dan mereka mau mengimplentasikan nilai-nilai hukum Islam dalam kehidupan di masyarakat maka membutuhkan lembaga peradilan. Oleh karena itu di dalam praktik, pengadilan Islam itu ada mula-mula melalui pengadilanpengadilan daerah kerajaan atau Kesultanan yang rajanya beragama Islam dan sebagainya.

Pengadilan-pengadilan itu berjalan dengan cara sendiri-sendiri baik mengenai nama lembaga maupun terhadap kekuasaan yang dimiliki. ${ }^{18}$ Sehingga nama peradilan Islam waktu itu ada yang bernama peradilan perdata, peradilan serambi, Mahkamah Syari'at, dan kerapan qadhi.

Perubahan paradigma peradilan hakam menjadi peradilan landraad sekarang ini dapat dirasakan dampaknya, yaitu usaha-usaha penyelesaian kasus sengketa tidak pernah lagi menggunakan lembaga perdamaian, tetapi langsung melalui jalur pengadilan. Pihak-pihak yang mempunyai kasus sengketa sudah tidak lagi mempertimbangkan kolektifitas. Sehingga perdamaian yang dipandang baik berdasarkan fungsi peradilan dalam Islam atau oleh sosial masyarakat telah ditinggalkan oleh profesioanl hukum. Sehingga Perma No. 2 tahun 2003 tentang Prosedur Mediasi di

${ }^{16}$ Ichtijanto SA, Hukum Islam dan Hukum Nasional, Ctk. 1, Jakarta: Ind-Hill Co, 1990, hlm. 23-25. Baca juga Daniel S. Lev Peradilan..........., Op. Cit., dalam halaman 43 lepas dari kenyataan bahwa banyak orang jawa yang beragama Islam yang menerima Hukum islam sedikit banyak semat-mata karena ketaatan "gama".

${ }_{17}$ Sajuti Thalib, Op. Cit. hlm 4.

${ }^{18}$ Busthanul Arifin, "Peradilan Agama Yang Kita Dambakan," Makalah Seminar Nasional Peradilan Agama dan Kesadaran Hukum Masyarakat: Kilas Balik 5 Tahun Undang-Undang Nomor 7 Tahun 1989, UII Yogyakarta, 1993 hlm. 2 
Pengadilan, dimana proses perdamaian dilakukan oleh hakim mediasi atau mediasi independen sebelum sidang perkara diperiksa oleh majelis hakim masih diabaikan sampai sekarang.

\section{Merubah belenggu hukum modern di kalangan profesional hukum}

Dalam konteks tulisan ini yang dimaksud profesional hukum adalah para praktisi hukum, yakni para penegak hukum. Kenapa para profesional ini menjadi titik penting pembahasan, karena para profesional inilah dianggap sebagai subyek yang mempunyai kewenangan mengatakan seseorang salah atau benar. Di sisi lain mereka juga sebagai anggota masyarakat yang hidup dalam lingkaran tatanan sosial masyarakat. Sehingga kadang-kadang antara peran dalam masing-masing bisa menimbulkan gap, padahal hukum itu hanya bisa berlaku efektif apabila antara aparat dan hukum terjalin pemahaman yang sama mengenai isi hukum dan mengapa hukum harus berbuat begini atau begitu kepada mereka. ${ }^{19}$

Dapat diakui keberadaan hukum modern di tengah-tengah masyarakat sudah berabad-abad, yaitu kurang lebih 3 abad. Keadaan yang demikian apabila dikaitkan dengan peletakan sistem bangunan peradaban manusia, maka kurang lebih ada empat generasi. Sehingga bangunan hukum modern yang diajarkan baik melalui jalur formal maupun informal sudah mengakar dalam ranah kehidupan masyarakat Indonesia.

Kondisi yang demikian sangat tidak mudah merubah belenggu hukum modern pada para profesional hukum kita. Sebagai mana kita ketahui bersama bahwa saintifikasi hukum modern sudah masuk pada bentuk formal. Misalnya syarat hakim, jaksa, advokat harus berijazah sarjana hukum. ${ }^{20}$

Sebagaimana kita ketahui bersama bahwa saintifikasi hukum modern sangat dipengaruhi oleh munculnnya paradigma positivisme di dalam ilmu pengetahuan modern. Karekteristik hukum modern bersifat rasional, yang ditandai sifat peraturan hukum yang prosedural. Sifat prosedural ini akhirnya menjadi dasar legalitas yang penting untuk menegakkan apa yang disebut keadilan, bahkan prosedur menjadi lebih penting dari pada

\footnotetext{
19 Satjipto Rahardjo, Biarkan.......Op. Cit., hlm.51

${ }^{20}$ Baca Satjipto Rahardjo, Biarkan.....Ibid., hlm. 13
} 
bicara tentang keadilan (justice) itu sendiri. ${ }^{21}$ Oleh karenanya materi hukum dirumuskan secara terukur dan formal dan menciptakan pada konsepkonsep khusus sehingga tidak setiap orang bisa menjadi operator hukum, melainkan mereka yang memiliki kwalifikasi khusus melalui bentuk pendidikan formal tertentu. ${ }^{22}$

Pelembagaan secara formal untuk memahami hukum tidak lain bertujuan agar memelihara kemurnian ajaran-ajaran hukum tersebut untuk menghasilkan praktisi-praktisi hukum yang mampu menerapkan peraturan-peraturan yang dilandasi doktrin-doktrin netralitas, imprialitas dan obyektifitas hukum. Outpun pelembagaan semacam itu akhirnya berdampak pada hasil, yaitu menghasilkan praktisi profesional hukum yang mampu membuat putusan pihak mana yang salah dan mana yang benar berdasarkan ketentuan hukum atau pasal undang-undang dan tidak sampai pada membuat suatu putusan yang adil. ${ }^{23}$

Kalau profesional hukum dalam hal berhukum tidak sampai pada dataran keadilan tetapi hanya salah benar berdasarkan kualifikasi hukum yang didasarkan teks-teks bunyi pasal undang-undang, maka hakim sebagai salah satu profesional hukum sering dinyatakan dalam ungkapan hanya sebatas "sebagai corong undang-undang", oleh karenanya peran pengadilan sebagai institusi hukum tempat orang mencari keadilan berubah peran menjadi kantor penerangan undang-undang, atau dalam istilah yang digunakan Satjipto peradilan perannya menjadi sempit yang teresolasi karena pengadilan tidak lebih dan tidak kurang hanya sebagai corong undang-undang. ${ }^{24}$

Hakim dalam menyelesaikan kasus sengketa dari para pencari keadilan sudah saatnya merubah belenggu paradigma lama, yaitu hukum tidak hanya difahami dari bentuk teks-teks bunyi pasal undang-undang, tetapi apa yang ada di belakang teks (legal reesening). Sebagaimana pendapat Gustav Radbruch yang dikutip Satjipto bahwa nilai hukum itu bertumpuh pada tiga nilai dasar, yaitu kepastian, keadilan dan kemanfaatan.

${ }^{21}$ Adji Samekto, Perkembangan ranah kajian Ilmu Hukum, Orasi Ilmiah di sampaikan pada Dies natalis ke-48 fakultas Hukum Univesitas Diponegoro. Pada 9 januari 2007, hlm. 16. Baca juga FX Adji Samekto, Study Hukum Kritis kritik terhadap Hukum Modern, Ctk. 1, Bandung: Citra Aditiya Bakti, 2005, hlm. 7-8

${ }^{22}$ Satjipto Rahardjo, Biarkan........, Loc. Cit. hlm. 13

${ }^{23}$ Baca Adji Samekto, Op. Cit, hlm. 16-17. Baca juga Satjipto Rahardjo

${ }^{24}$ Satjipto Rahardjo, Membedah Hukum Progresif, Ctk. Kedua, Jakarta: Penerbit Buku Kompas, 2007, hlm.38 
Ketiganya selalu ada dan mendasari kehidupan hukum, meskipun ketiganya tidak selalu dalam keadaan dan hubungan yang harmonis. ${ }^{25}$ Para profesional hukum harusnya sampai pada dataran mencari apa filosofi pasal itu, atau mencari apa manfaat pasal itu dibuat bagi manusia, kalau tidak manfaat boleh tidak pasal itu disimpangi.

Menurut penulis, untuk mencapai suatu hukum yang adil sebaiknya para profesional hukum harus berani meninggalkan cara berhukum modern dan kembali kepada cara berhukum yang sesuai dengan kehidupan sosial masyarakat yang hkas (a peculiar form of sosial life). Kalau dahulu masyarakat mengenal lembaga perdamaian dalam menyelesaikan masalah atau kasus sengketa, mengenal peradilan adat, maka para profesional hukum dapat menggunakan jalur itu kemudian diambil sebagai dasar putusan pengadilan.

Peluang semacam itu oleh hukum kita sudah diakomodasi, yaitu melalui Perma No. 2 tahun 2003, meskipun masih terbatas pada hukum perdata. Persoalannya bagaimana kemauan kita untuk berijtihad di luar teks-teks perma, bukan berarti profesional hukum dilarang menggunakan dasar perdamaian sebagai pertimbangan dalam hukum pidana. Sehingga penyelesaian yang berbasis pada a peculiar form of sosial life tidak hanya sekedar life tetapi usaha yang nyata.

Jalan keluar untuk melepaskan diri dari belengku hukum modern bagi profesional hukum adalah berani menggunakan ijtihad terhadap teks yang ada dalam pasal-pasal undang-undang. Kalau para profesional tidak berani berijtihad maka bunyi teks undang-undang menjadi sesuatu yang dianggap sebagai suara Tuhan yang bersifat mutlak. Padahal bisa jadi bunyi teks itu salah atau bertentangan dengan a peculiar form of sosial life tetapi itu adalah hasil proses legalitas yang dianggap prosedural atau proses politik, maka pasal tersebut dianggap benar. Dampaknya bisa jadi banyak para pencari keadilan yang tidak mendapatkan keadilan di negara yang menjunjung tinggi keadilan.

\section{Kritik terhadap Hukum Modern (Barat) Menghadapi Perkembangan Manusia}

Manusia adalah tergolong mahluk hidup yang mempunyai akal pikiran. Dan dengan akal pikiran tersebut dapat membimbing manusia

${ }^{25}$ Satjipto Rahardjo, Biarkan..., Op. Cit., hlm. 80-81 
untuk bisa mempunyai keinginan, dan keinginan itulah yang mendorong manusi untuk berubah. Perubahan manusia dari satu pereode ke pereodelainnya senantiasa dipengaruhi oleh intelektual manusia tersebut. Perunahan itelektual senantiasa dihubungkan dengan teknologi.

Kemanjuan teknologi yang berkembang sejak kurang lebih tahun 80 an dikenal dengan istilah globalisasi. Globalisasi yang menurut Samodra Wibawa bahwa terjadinya globalisasi diantaranya karena perkembangan teknologi, baik tranportasi, komunikasi maupun pruduksi. Karena teknologilah bangsa-bangsa di dunia mampu menjelajahi berbagai belahan dunia. ${ }^{26}$ Sedangkan G.C. Lodge sebagai mana dikutip oleh Budi Winarno, bahwa globalisasi suatu proses yang menjadikan masyarakat (dunia) makin luas saling terhubungkan dalam semua aspek kehidupan mereka, baik budaya, ekonomi, politik, teknologi, maupun lingkungan. ${ }^{27}$

Dari penjelasan singkat tersebut, dapat difahami bahwa pengaruh globalisasi yang paling dominan adan dua, yaitu: (1) kemajuan teknologi, (2) perubahan budaya manusia. Kemajuan teknologi yang berkembang dewasa ini jelas akan berdampak pada perubahan budaya manusia. Seperti contoh, kalau dahulu orang berkomunikasi antar daerah, negara, benua yang satu dengan yang lain dengan menggunakan surat, kalau tidak hilang di jalan juga memakan waktu yang lama, bisa berbulanbulan. Kemudian ini disederhanakan dengan telepon, fax dan sekarang bisa melalui telekonfrens atau internet dan sms.

Pemanfaatan kemajuan teknologi ini membawa dampak pada perubahan budaya manusia. Misalnya para pelaku bisnis internet dimanfaatkan sebagai jalan untuk memperlancar hubungan bisnis yang tidak mungkin dilakukan secara cepat. Sehingga para pelaku bisnis mempermudah bahkan cenderung tidak formal dalam melakukan hubungan bisnis. Sebagai contoh, para pelaku bisnis menawarkan barangnya tidak lagi dengan cara berkeliling atau memasang di etalase tokonya, tetapi tinggal memasukkan gambar barang dan spisifikasi barang yang ditawarkan di dalam internet. Pihak pembeli juga sama tidak perlu jalan-jalan ke Jepang, Amirika, Eropa dan lain sebagainya. Barang-barang yang ada dibenua yang berbeda atau ditempat yang jauh dengan pembeli dapat dilihat secara cepat tinggal mencari iklaniklan di internet.

${ }^{26}$ Samodra Wibowo, Reformasi Administrasi, Bunga Rampai Pemikiran Administrasi Negara Publik, Yogyakarta: CV Media, 2005. 321

27 Budi Winarno, Globalisasi Wujud Imperialisme Baru, Peran Negara dalam Pembangunan, Yogyakarta: Tajidu Press, 2003, 39 
Apabila antara penjual dengan pembeli ternyata ada kecocokan barang dan harga, maka keduanya melanjutkannya jual beli melalui internet, termasuk cara membayarnya. Fenomena semacam ini tentu saja pemaknaan jual beli di kalangan masyarakat pada era globalisasi sudah bergeser, tidak lagi seperti pada paradigma hukum moderen (Barat) yang berlaku di indonesia saat ini.

Gambaran tersebut di atas manakala dikontekkan hukum yang dirumuskan dalam hukum positif tentu saja tidak sesuai dengan rumusan hukum jual pada umumnya. Termasuk hukum pembuktian pada umumnya. Sebagai contoh ketika pembeli menyetujui jual beli dengan cara membayar melalui kartu kredit yang dikirim lewat internet, pihak pembeli tidak mempunyai bukti secara formal karena pihak penjual juga tidak secara langsung menerima uang tunai melainkan rekening yang ada di bank. Ketika penjual mengecek apakah benar pembeli sudah membayar, dan di rekeningpun tidak keluar dalam prin out nama pembeli. Sehingga penjual dan pembeli sama-sama tidak membuat bukti surat dengan menyerahkan kwitansi pembelian seperti pada proses jualbeli konvensional. Dalam model jula beli di ere globalisasi ini ada pihak yang tidak memenuhi kuwajibannya, misalnya pihak penjual tidak mengirim barang yang sudah dibeli melalui internet tidak dikirim, berarti pihak penjual telah melakukan wanprestasi. Kalau pihak pembeli merasa dirugikan atas perbuatn seperti itu dan dia menyelesaikan secara hukum, maka persoalan yang demikian tidak mungkin akan diselesaikan secara normatif berdasarkan hukum positif.

Kasus sengketa tersbut apakah itu bukan persoalan hukum, lalu apakah dapat diselesaiakan ? kalau dapat, hukum apa yang digunakan sebagai dasar? atau kalau tidak dapat diselesaikan, apakah itu tidak berarti ada pihak lain yang dirugikan ? terus bagaimana cara penyelesiaannya?. Inilah perlunya kritik terhadap faham positivisme dimana hukum hanya dimaknai sebagi normatif saja, maka hukum moderen (Barat) yang berlaku di indonesia tidak akan mampu menjawab persoalan sengketa kasus di era globalisasi ini manaka kita masih terbelenggu oleh paradigma positivitik

Contoh perkembangan hukum di era globalisasi tersebut apabila hanya menngunakan cara pandang legal formal (positivistik) semata maka manusai akan mengalami soch, karena hukum yang bertugas menjaga ketertiban (order) malah menimbulkan kekacauan (disorder). Bisa-bisa meskipun era globalisasi tetapi budaya manusia akan mengalami titik balik (the Turning Point) kepada dunia primitif atau setidak-tidaknya kembali pada budaya konfensional. Sebab hukum tidak mampu menjawab 
tantangan kemajuan jaman moderen yang berkembang terus seiring perkembangan intelektual manusia.

Fenomena ini membuka mata kita untuk memikirkan yang akhirnya mempunyai kesimpulan bahwa hukum tidak dapat dipisahkan dengan ilmu-ilmu lain, sebagaimana pendapat Edward O. Wilson dalam buku Consillience, bahwa ilmu tidak dapat dipisahkan satu dengan ilmu yang lain, bahkan ilmu alam dengan sosial sangat erat hubungannya, ${ }^{28}$ Kenapa consilience dibutuhkan untuk memahami hukum agar jangan samapai hukum tertinggal dengan peradaban manusia. Selama ini hukum seolaholah terpisah dengan ilmu lain, karena selama ini di dalam paradigma ilmu sosial terdapat kesalahan yang mendasar ilmu-ilmu sosial adalah membagibagi susunan ini menjadi potongan-potongan, yang dianggap mandiri dan dihadapi dalam bidang akdemik yang terpisah. ${ }^{29}$ Termasuk ilmu hukum yang masih memisahkan dengan ilmu-ilmu lain untuk memahami kasus sengketa. Sehingga dalam kondisi tertentu hukum akan mengalami kemandegan.

Untuk menjaga agar jangan sampai hukum mengalami kemandegan atau aturan hukum tidak dapat menjalankan fungsinya di manapun zamannya. Gagasan yang ditawarkan adalah hukum responsif dari teori Nonet dan Selznick dan hukum progresif dari Satjipto Rahardjo.

Teori hukum responsif yang dikembangkan oleh Philippe Nonet dan Philip Selznick. Teori ini menawarkan model hukum yang bersifat responsif. Model ini ditawarkan ketika hukum tengah dikritik Neo-Marxis terhadap liberal legalism, yang mengandaikan hukum sebagai institusi mandiri dengan sistem peraturan dan prosedur yang obyektif, tidak memihak, dan benar-benar otonom..$^{30}$ Pendapat Neo-Marxis lebih lanjut bahwa otonomi hukum ada doktrin yang tersembunyi, yaitu ideologi status quo, padahal status quo sendiri merupakan canopy (benteng perlindungan) bagi orang-orang mampu, orang-orang berpunya. ${ }^{31}$

Kritik yang dilakukan oleh Neo-Marxis sebagaimana dikutip Bernard L Tanya dkk ada dua pertama, keberpihakan hukum menguntungkan golongan kaya dan merugikan serta menipu golongan miskin. Dengan

${ }^{28}$ Edwado Wilson, Consilience the Unity of Knowlege, New York: Alfreda A. Knopp, 1998, hlm. 11-15

${ }^{29}$ Fritjof Capra, The Turning Point, diterjemahkan M. Toyibi, (titik balikperadaban sins, masyarakat, dan kebangkitan kebudayaan), Ctk. Ketujuh, Yogyakarta: Jejak, 2007, hlm. 219

${ }^{30}$ Bernard L Tanya dkk, Teori Hukum strategi Tertib manusia Lintas Ruang dan Generasi, Ctk. Pertama, Surabaya: CV Kita, 2006, hlm. 169.

${ }^{31} \mathrm{Ibid}$, 
begitu, secara tersembunyi institut-institut hukum telah tercemar dan ikut menyebabkan ketiadaan ketertiabn sosial secara keseluruhan. Ia bekerja sebagai alat kekuasaan. Kedua adalah ligalisme liberal (liberal legalism), khususnya mengenai gagasan bahwa tujuan keadilan dapat dicapai melalui sistem peraturan dan prosedur yang obyektif, tidak memihak, dan otonom adalah faktual the rule of law tidak mampu mengatasi isu-isu mendasar mengenai keadilan sosial, dan lebih buruk lagi rule of law merupakan "musuh tersebunyi" bagi keadilan sosial itu sendiri. ${ }^{32}$

Setelah melakukan ritik Nonet dan Selznick melalui hukum responsif menempatkan hukum sebagai sarana respon terhadap ketentuanketentuan sosial dan aspirasi publik. Karena sifatnya terbuka, maka tipe hukum ini mengedepankan akomodasi untuk menerima perubahanperubahan osial demi tercapainya keadilan dan emansipasi publik. ${ }^{33}$

Selaras dengan teori hukum responsif, yaitu hukum progresif yang digagas oleh Satjipto Rahardjo. Gagasan ini dilandasi oleh paradigma bahwa hukum adalah untuk manusia dan bukan untuk sebaliknya. Apabila manusia adalah untuk hukum, maka dinamika masyarakat akan terhambat, maka mungkin berhenti, saat dihadapkan pada hukum yang mempertahankan status quo itu. Sebaliknya, apabila hukum adalah untuk manusia, maka ia tidak boleh menjadi hambatan untuk menyalurkan dinamika masyarakat. ${ }^{34}$

Pendapat satjipto ini nampaknya dilihami oleh teori Nonet dan Selznick yang intinya mengatakan, bahwa hukum itu hendaknya mencerminkan dinamika kekuatan-kekuatan dalam masyarakat. Janganlah hukum itu mempertahankan dan memaksakan suatu konstruksi yang bertentangan dengan dinamika tersebut. ${ }^{35}$

Dari teori-teori tersebut dapat disimpulkan bahwa untuk menjawab persoalan hukum di era globalisasi adalah teori hukum responsif dan teori hukum progresif. Sebab dalam teori ini hukum dapat mengikuti perkembangan budaya manusia tanpa meninggalkan teks-teks undangundang, bukan sebaliknya sebaliknya manusia dipaksa untuk mengikuti beunyi teks-teks pasal dalam undang-undang, sehingga ketentuan hukum tidak dapat berkembang mengkuti perkembangan intelektual manusia.

\footnotetext{
${ }^{32}$ Ibid., hlm. 169-170

${ }^{33}$ Ibid., hlm. 170

${ }^{34}$ Satjipto Rahardjo, Biarkan........., Op. Cit, hlm. 47. Baca Bernard L dkk, Ibid, hlm. 176-177

${ }^{35}$ Satjipto Rahardjo, Ibid, hlm. 48
} 


\section{Penutup}

Dari uraian tersebut di atas dapat penulis simpulkan sebagai berikut:

1. Hukum modern telah merubah paradigma lembaga perdamaian (hakam) ke pengadilan, sehingga berdampak pada cara pandang antara konsep hukum modern (Barat) dengan hukum lokal. Dampak yang lebih luas adalah terhadap pemaknaan nilai-nilai yang hidup dalam sosial masyarakat yang sudah dijalankan berabad-abad.

2. Cara berhukum para profesional hukum sampai sekarang ini dapat dibedakan menjadi dua, yaitu: profesional hukum yang praktis (normatif) dan para profesional progresif. Profesional hukum yang praktis disebabkan karena sulit meninggalkan cara-cara berhukum model hukum modern yang telah dikembangkan oleh kolonial penjajah. Hal ini dikarenakan hukum modern dikembangkan melalui jalur pendidikan sudah berabad-abad. Sehingga berdampak pada: (a) penyelesaian kasus sengketa dipandang mempunyai kepastian hukum apabila didasarkan pada putusan pengadilan yang mengambil hukum positif. (b) para profesional hukum tidak mau mengubah belenggu hukum modern dalam cara berhukum. (c) positivisme lebih praktis dalam menyelesaikan kasus sengketa, karena hukum modern sudah logis dan terukur, sehingga tidak perlu ditafsirkan lagi. Profesional hukum progresif adalah mereka yang mau meninggalkan belenggu cara berhukum hukum modern, meskipun lebih berat. Sebab profesional hukum yang macam ini harus menggali teks-teks pasal undang-undang dengan cara menggali sesuatu yang menjadi resening atau sesuatu yang ada di luar teks. Karena yang dicari adalah keadilan bukan kebenaran.

3. Kritik terhadap hukum modern mengenai perkembangan manusai, hukum modern tidak dapat mengikuti perkembangannya manusia. Contoh saja di era globalisasi ini, paradigma manusia tentang perbuatan hukum sudah berkembang, dari hukum formal (normativ) menuju hukum bebas. Misalnya kalau dalam tatanan hukum modern yang berlaku di Indonesia difahami kalau orang melakukan jual beli. Hukum modern (normativ) paradigmanya orang membuat perjanjian dalam bentuk formal, sekarang tidak. Di era globalisasi ini orang bisa saja melakukan jual beli melalui internet (tidak dalam bentuk formal) termasuk cara bayarnya. Sehingga penjual tidak pernah mengeluarkan 
kwitansi, sebab paradikmanya adalah kepercayaan. Bagaimana kalau ada pihak penjual wanprestasi tidak mengirim barangnya, misal penjual ada di Jepang. Mau digugat di mana dan seterusnya yang menyangkut hukum prosedur penyelesaian tidak akan lagi menjangkau. Kalau begitu ada pihak yang dirugikan, terus bagaimana rasa keadilan terhadap pembeli. Itulah sebabnya para profesional hukum sudah harus meninggalkan paradigma lama.

\section{Daftar Pustaka}

Bernard L Tanya dkk, Teori Hukum strategi Tertib manusia Lintas Ruang dan Generasi, Ctk. Pertama, Surabaya: CV Kita, 2006,

Budi Winarno, Globalisasi Wujud Imperialisme Baru, Peran Negara dalam Pembangunan, Yogyakarta: Tajidu Press, 2003

Busthanul Arifin, "Peradilan Agama Yang Kita Dambakan," Makalah Seminar Nasional Peradilan Agama dan Kesadaran Hukum Masyarakat : Kilas Balik 5 Tahun Undang-Undang Nomor 7 Tahun 1989, UII Yogyakarta, 1993

C.F.G. Sunaryati Hartono Sunario, "Pembinaan Hukum Nasiona Dalam Suasana Globalisasi masyarakat Dunia". Pidato Pengukuhan jabatan Guru Besar dalam Ilmu Hukum FH UNPAD, Bandung, 1991

Daniel S. Lev, Peradilan Agama Islam di Indonesia, alih bahasa H. Zaini Ahmad Noeh, Ctk . kedua, Jakarta: Intermasa, 1986 , Hukum dan Politik di Indonesia Kesinambungan dan Perubahan, penterjemah Wiyono dan AE. Priyono, Ctk. Pertama, Jakarta: 1990.

Edwad O Wilson, Consilience the Unity of Knowlege, New York: Alfreda A. Knopp, 1998,

Fritjof Capra, The Turning Point, diterjemahkan M. Toyibi, (titik balik peradaban sins, masyarakat, dan kebangkitan kebudayaan), Ctk. Ketujuh, Yogyakarta: Jejak, 2007

FX Adji Samekto, Studi Hukum Kritis kritik terhadap Hukum Modern, Ctk. 1, Bandung, Citra Aditiya Bakti, 2005.

, "Orasasi ilmiah Perkembangan ranah kajian Ilmu Hukum", Disampaikan pada Dies natalis ke-48 fakultas Hukum Universitas Diponegoro, Semarang 9 Januari 2005

Ichtijanto SA, Hukum Islam dan Hukum Nasional, Ctk. 1, Jakarta: Ind-Hill Co, 1990 
Hadari Djenawi Thaher, "Pokok-pokok Pikiran Dalam UU Peradilan Agama," dalam Undang-Undang Peradilan Agama : UU RI Nomor 7 Tahun 1989, Jakarta : Alda, 1989,

Mohammad Daud Ali, Hukum Islam Hukum Islam : Pengantar Ilmu Hukum dan Tata Hukum Islam di Indonesia, Edsi kelima, Ctk.5, Jakarta : Raja Grafindo Persada, 1996

Sajuti Thalib. Receptio A Contrario Hubungan Hukum adat dengan Hukum Islam, Ctk. Keempat, Jakarta: Bina Aksara, 1985,

Samodra Wibowo, Reformasi Administrasi, Bunga Rampai Pemikiran Administrasi Negara Publik, Yogyakarta: CV Media, 2005

Satjipto Rahardja, Hukum dalam Jagat Ketertiban, bacaan mahasiswa Program Doktor Ilmu Hukum Universitas Diponegoro, Ctk. 1 Jakarta: UKI Press, 2006 , Membedah Hukum Progresif, Ctk. Kedua, Jakarta: Penerbit Kompas, 2007.

,Biarkan Hukum Mengalir Catatan Kritis tentang Pergulatan Manusia dan Hukum, Jakarta: Penerbit Kompas, 2007

, "Kemajemukan sebagai Konsep Hukum" makalah Bacaan mahasiswa calon doktor Undip dalam matakuliah ilmu hukum dan teori hukum No. 24, kuliah 20 Nopember 2007. 